Research Article

\title{
Immobilization of Purified Pectin Lyase from Acinetobacter calcoaceticus onto Magnetic Carboxymethyl Cellulose Nanoparticles and Its Usability in Food Industry
}

\author{
Esen Tasgin $\mathbb{D}^{1,},{ }^{1,2}$ Aynur Babagil, ${ }^{2}$ and Hayrunnisa Nadaroglu $\mathbb{D}^{2,3}$ \\ ${ }^{1}$ Department of Nutrition and Dietetics, Faculty of Health Sciences, Ataturk University, 25240 Erzurum, Turkey \\ ${ }^{2}$ Department of Nano-Science and Nano-Engineering, Institute of Science and Technology, Ataturk University, \\ 25240 Erzurum, Turkey \\ ${ }^{3}$ Department of Food Technology, Vocational College of Technical Science, Ataturk University, 25240 Erzurum, Turkey
}

Correspondence should be addressed to Esen Tasgin; esent25@atauni.edu.tr and Hayrunnisa Nadaroglu; hnisa25@atauni.edu.tr Received 18 June 2020; Revised 4 August 2020; Accepted 21 August 2020; Published 29 September 2020

Academic Editor: Patricia E. Allegretti

Copyright (c) 2020 Esen Tasgin et al. This is an open access article distributed under the Creative Commons Attribution License, which permits unrestricted use, distribution, and reproduction in any medium, provided the original work is properly cited.

An important component of the pectinase enzyme complex is pectin lyase (polymethylgalacturonate lyase; EC 4.2.2.10). In this study, extracellular pectin lyase enzyme was produced from Acinetobacter calcoaceticus bacteria. Pectin lyase was then purified using three-phase precipitation (TPP) technique with $25.5 \%$ yield. The pectin lyase was immobilized covalently via the L-glutaraldehyde spacer to the carboxymethyl cellulose. The immobilized pectin lyase was magnetized using $\mathrm{Fe}_{3} \mathrm{O}_{4}$ nanoparticles. Purified pectin lyase was connected to magnetized support material after $90 \mathrm{~min}$ at the rate of $80 \%$. The most appropriate immobilization conditions were determined as $\mathrm{pH} 8$ and $30^{\circ} \mathrm{C}$. By characterizing the free and immobilized enzyme, $K_{\mathrm{M}}, V_{\max }$, and optimum $\mathrm{pH}$ and optimum temperature values were determined. It was optimum $\mathrm{pH} 8$ and temperature $50^{\circ} \mathrm{C}$ for both free and immobilized pectin lyase. The structural characterization of the immobilized pectin lyase modified with $\mathrm{Fe}_{3} \mathrm{O}_{4}$ nanoparticles was carried out by SEM, FT-IR, and XRD chromatographic analyses. At the end of the study, free and immobilized enzymes were used for purification of some fruit juices and results were compared.

\section{Introduction}

Pectinases are produced by a large number of organisms, such as bacteria, fungi, and yeasts. They are involved in the breakdown of complex and long structural polysaccharides known as pectin [1]. Pectinases are classified into three types as pectin esterase, hydrolases (polygalacturonases and polymethylgalacturonases) and lyase (polygalacturonate lyase and polymethylgalacturonate lyase) according to their mode of action $[1,2]$. Pectin esterase catalyzes deesterification by removing the methoxyl group of pectin. While polygalacturonases catalyze the polygalacturonic acid chain hydrolytically, lyases perform nonhydrolytic cleavage of pectates or pectinates. As product in these reactions, pectic acid and methanol (by catalysis of esterases), oligo methylgalacturonate (by catalysis of hydrolases), and unsaturated methyl oligo-galacturonates (by lyases catalysis) are mostly produced [2]. Only pectin lyase (PNL) break down highly methylated and unesterified pectin through the elimination mechanism without the production of methanol, and this is very important for pectin lyase. Methanol is a nondesirable product, especially in the paper, food, and textile industries due to its toxicity and unpleasant taste. So, pectin lyase generally is preferred in the food industry [3]. In addition, thanks to this important role of PNL enzymes in the plant tissues, they are used effectively in the processing of the textile industry, in paper making, in the treatment of waste water, and especially in the processing of products such as fruit juice, vinegar, and wine. In particular, the desire to use environmentally friendly enzymes in the industry further increases the importance of this ecofriendly enzyme [2]. It has been reported that most of the pectin lyases studied so 
far have been obtained from microorganisms and have insufficient presence in plants and animals. Microbial pectinases have accounted for $25 \%$ of the global food and industrial enzyme [3]. Although some chromatography techniques such as CM-Cellulose, Sephadex G-100 column chromatographies, and DEAE-Sepharose ion exchange are used for purification of enzymes [4]; the triple phase separation method has been preferred more in recent years. In this preference, it is effective that other methods take longer and cause depolymerization [5-7].

Processed fruit-based drinks, juices, and wines are blurry. This turbidity is caused by the suspension of polysaccharide particles (pectin, cellulose, hemicellulose, starch, and lignin) originating from the primary and internal cell walls [8]. Pectinases are responsible for the breakdown of the structural polysaccharides of fruit pulp [9] and the addition of pectinases to the juice reduces its viscosity, disintegrating the jelly structure, and increasing the fruit juice yields [9].

Immobilized enzymes are used to optimum performances because they have more advantages than free enzymes [10]. In some research, immobilized enzymes for the clarification of orange, apple, pineapple, grape, and carrot juices were utilized [9]. In enzyme technology, enzyme immobilization has been made lately using different support materials. Support materials are very important as they protect the structure and activities of enzymes against difficult reaction conditions $[10,11]$. Immobilization has been performed to protect the activities of enzymes for a long time and to use them repeatedly [11]. In recent years, natural source polymers have been used as support materials for the immobilization of enzymes. In general, natural polymers are preferred as support materials due to their biocompatibility, high affinity for proteins, biodegradability to harmless products, and nontoxic properties [12]. Materials such as chitin-chitosan $[13,14]$, alginate $[5,15,16]$, collagen, cellulose, and agarose [17-19] are mostly preferred as immobilization support biopolymers. Hydroxyl, amine, and carbonyl groups of large biopolymers such as cellulose, hemicellulose, lignin, and pectin provide rapid interaction with enzymes [20]. As the renewability and availability of cellulosic materials are easy, the immobilization costs are much lower [21]. In general, natural cellulosic polymers are preferred as support materials since they are biocompatible and nontoxic $[22,23]$. The cellulosic polysaccharide structure of the carboxymethyl cellulose (CMC) is thought to be a potential candidate for immobilization of the pectin lyase enzyme such as other cellulosic supports [24, 25]. Therefore, for this study, carboxymethyl cellulose, which is nontoxic and easily accessible, has been selected as a support material.

The aim of this study is to purify and characterize the pectin lyase enzyme obtained extracellularly from Acinetobacter calcoaceticus bacteria, which is purified from parsley leaves and diagnosed using the 16SRNA technique, and covalently immobilized on CMC surface magnetized with $\mathrm{Fe}_{3} \mathrm{O}_{4}$ NPs. In the last stage of the study, it was aimed to investigate the use of immobilized PNL enzyme in the clarification of some fruit juices.

\section{Materials and Methods}

2.1. Bacterial Isolation. In this study, microorganism was isolated from parsley obtained from Erzurum local markets. A sample was prepared from the parsley sample at $10 \mu \mathrm{g} / \mathrm{mL}$ concentration under aseptic condition. Subsequently, serial dilutions from $10^{-1}$ to $10^{-8} \mathrm{CFU} / \mathrm{mL}$ were prepared using physiological serum. Foods from each dilution were spread onto agar medium and then incubated at $34^{\circ} \mathrm{C}$ for 48 hours. After incubation, nutrient agar medium was drawn from typical colonies developed and drawing was made by drawing 3 phases. This was continued until pure colonies were obtained. The purified colony was then transferred to nutrient broth containing $20 \%$ glycerol solution. It was then stored as a stock culture at $-80^{\circ} \mathrm{C}$.

2.2. Identification Tests. In this study, among general identification tests, Gram staining and catalase tests were performed on isolated microorganism. According to the results of microbiological analysis, it was found to be Gram positive and catalase positive.

2.3. Identification of Microorganism. After isolating microorganisms from parsley, pure cultures obtained at species level were identified. For this purpose, after DNA isolation from pure culture was done, identification was made by means of the sequence analysis of intergenic spacer regions (ISR) of genes $16 \mathrm{~S}$ rRNA and 16S-23S rRNA, which is considered as the most reliable method in microbial identification [26].

2.4. Genotype Characterization of Bacteria. For the sequence analysis of the $16 \mathrm{~S}$ rRNA genes, universal primers LPW57 (5 W-AGTTTGATCCTGGCTCAG-3') and LPW205 (5'CTTGTTACGACTTCACCC-3 T) [27] were used. In the amplification of the ISR region, $16-1 \mathrm{~A}$ (GTCGGAATCGCTAGTAATCG) and 23-1B (GGGTTCCCCCATTCGGA) [28] universal primers were used. Sequence analysis was made by Medsantek (Istanbul, Turkey) company. The results of complete sequence analysis of $16 \mathrm{~S}$ rRNA and 16S-23S rRNA intergenic spacer region (ISR) were compared with those of other bacterial sequences in GenBank (http://blast.ncbi.nlm.nih.gov/blast.cgi). Similarity ratio was determined [26]. According to this ratio, it was found that the purified isolate was $99 \%$ similar to the Acinetobacter calcoaceticus bacteria.

\subsection{PNL Enzyme Production with Solid Culture Fermentation.} PNL enzyme from Acinetobacter calcoaceticus bacteria produced in solid culture medium was purified and characterized by three-phase precipitation (TPP) technique [6]. For this purpose, first, $n$-butanol concentration optimization was done to purify the PNL enzyme and then concentration optimization of ammonium sulfate. Briefly, the amount of ammonium sulfate in the reaction medium was kept constant and different $n$-butanol ratios $(1: 0.5,1.0: 1.0,1.0: 1.5$, and $1.0: 2.0)$ precipitation was performed in three phases. 
Next, the precipitate middle phase was dissolved in $1 \mathrm{~mL}$ of $0.05 \mathrm{M}$ phosphate buffer ( $\mathrm{pH} 8.0$ ) and dialyzed against the same buffer during 3 hours.

2.6. Purification of PNL from Acinetobacter calcoaceticus Using the TPP Method. PNL enzyme, which was produced extracellularly from Acinetobacter calcoaceticus bacterium, was purified by triple phase separation (TPP) method [6, 7]. For the optimization of ammonium sulfate, PNL was precipitated by adding different ammonium sulfate ratios $(20 \%$, $40 \%, 60 \%$, and $80 \%$ ammonium sulfate) to the homogenate medium at the optimum $n$-butanol ratio $(1.0: 0.5 \%)$. Then, the percentages were determined according to the optimum amount of $n$-butanol and ammonium sulfate. Purification of PNL enzyme was carried out according to the parameters obtained. PNL enzyme activity was determined by measuring the obtained color change intensity [29].

2.7. PNL Activity Assay. Pectin lyase activity was determined by using thiobarbituric acid (TBA) method, as described by Nedjma [29]. A suitably diluted enzyme solution $(250 \mu \mathrm{L})$ was incubated in the presence of $250 \mu \mathrm{L}$ of substrate $(1.5 \%$ $(\mathrm{w} / \mathrm{v})$ pectin (DE 93\%)/0.05 $\mathrm{M}$ phosphate, $\mathrm{pH}$ : 8) for the duration 10 minutes. $\mathrm{NaOH}(1 \mathrm{~N}, 0.05 \mathrm{~mL})$ was added to $0.5 \mathrm{~mL}$ of the sample. The mixture was shaken briefly. The solution was heated at $80^{\circ} \mathrm{C}$ in a water bath for $5 \mathrm{~min}$ and cooled. After the addition of $0.6 \mathrm{~mL}$ of $\mathrm{HCl}(1 \mathrm{~N})$ to acidify the medium, the solution was then shaken and $0.5 \mathrm{~mL}$ of $0.04 \mathrm{M}$ thiobarbituric acid (in aqueous solution) was added. The tube was then heated at $80^{\circ} \mathrm{C}$ for $5 \mathrm{~min}$ in a water bath. The optical density of the resulting colored derivative was measured at $550 \mathrm{~nm}$ using BioTek's EpochTM Multi-Volume Spectrophotometer (BioTek Instruments, Winooski, VT, USA) [29]. The blank sample was prepared using phosphate buffer instead of enzymes. The one unit of activity ( $1 \mathrm{EU})$ was defined as the amount of enzyme converting $1 \mu \mathrm{mol}$ substrate into product in 1 minute at $25^{\circ} \mathrm{C}$ under standard conditions. All experiments were repeated three times.

2.8. Enzyme Immobilization. The enzyme was covalently immobilized to the cellulosic structures of carboxymethyl cellulose support material via the L-glutaraldehyde spacer (Figure 1). For this purpose, first, $1 \mathrm{~g}$ carboxymethyl cellulose (CMC) was mixed in distilled water and filtered. The solid material was stirred with $1 \mathrm{~N} \mathrm{NaOH}$ for 1 hour (at $350 \mathrm{rpm}$ ) and then washed with distilled water until the support material was neutralized. Magnetic CMC was prepared by treating $\mathrm{CMC}$ molecule with $\mathrm{Fe}_{3} \mathrm{O}_{4}$ NPs. For this purpose, $0.10 \mathrm{~g}$ of $\mathrm{Fe}_{3} \mathrm{O}_{4}$ NPs were completely dispersed in $\mathrm{CMC}$ solution under ultrasonic vibration for 30 minutes [30] and then unbound $\mathrm{Fe}_{3} \mathrm{O}_{4}$ NPs were washed away with distilled water. Thus, CMC was made magnetic by being modified with $\mathrm{Fe}_{3} \mathrm{O}_{4}$ nanoparticles. Magnetic CMC NPs were treated with $5 \%$ L-glutaraldehyde solution for 4 hours. It was then washed with hexane, ethyl alcohol, and distilled water in vacuum to remove nonbinding glutaraldehyde, respectively. The PNL enzyme $(30 \mathrm{EU} / \mathrm{mL})$ was then covalently bound to $1 \mathrm{~g}$ magnetic CMC nanoparticles using an ultrasonic bath [30]. The amount of protein was monitored during the reaction using the Bradford method, and the amount of PNL enzyme bound was determined against the reaction time [31].

2.9. Protein Determination. Protein concentration of samples was determined spectrophotometrically by using the Bradford method [31]. Bovine serum albumin (BSA) was used as a standard.

2.10. Determination of Optimum Conditions for Immobilization of Purified PNL Enzyme onto Modified CMC with $\mathrm{Fe}_{3} \mathrm{O}_{4}$ NPs. To find the $\mathrm{pH}$ value with the highest immobilization rate, covalent immobilization of the PNL enzyme to the magnetic CMC surface was performed at different $\mathrm{pHs}$ ranging from $\mathrm{pH}: 2.0$ to 8.0. Also, in order to find the highest rate of immobilization occurring in which temperatures, immobilization was carried out at 10, 15, 30, 40, 50, 60, 70, and $80^{\circ} \mathrm{C}$ in previously determined $\mathrm{pH}$. follows:

The pectin lyase binding efficiency $(E)$ is defined as

$$
E=\frac{\left(C_{1}-C_{\mathrm{o}}\right)}{C_{1}} \times 100 .
$$

$C_{1}$ and $C_{\mathrm{o}}$ are the amounts of pectin lyase protein in the solution before and after immobilized, respectively.

The activity amount of the immobilized pectin lyase was calculated as follows:

$$
\text { immobilized pectin lyase }=\frac{\left(A_{1}-A_{\mathrm{o}}\right)}{A_{1}} \times 100 .
$$

$A$ is the activity of the immobilized pectin lyase and $A_{1}$ and $A_{\mathrm{o}}$ are the activities of the free pectin lyase in solution before and after immobilization, respectively.

2.11. Determination of the Optimum $p H$ and Stable $p H$. The effect of $\mathrm{pH}$ on the activity and stability of free pectin lyase and immobilized pectin lyase was identified. The optimum $\mathrm{pH}$ of the PNL was determined at a fixed assay temperature of $50^{\circ} \mathrm{C}$ at various $\mathrm{pH}$ values between $\mathrm{pH} 4$ and 11 , using different buffers. Buffers used were $20 \mathrm{mM}$ sodium acetate ( $\mathrm{pH} 4.0-5.0), 20 \mathrm{mM}$ sodium phosphate $(\mathrm{pH}$ 6.0-7.0), $20 \mathrm{mM}$ Tris- $\mathrm{HCl}$ ( $\mathrm{pH} 8.0-9.0$ ), and $20 \mathrm{mM}$ sodium carbonate buffer ( $\mathrm{pH}$ 10.0-11.0). pH stability was tested by activity monitoring by incubating at $4^{\circ} \mathrm{C}$ in the above-mentioned buffer solutions at different $\mathrm{pHs}$ at a concentration of $20 \mathrm{mM}$ during 1 week.

\subsection{Determination of Optimum and Stable Temperature} Values. PNL activity measurements were performed at $10-90^{\circ} \mathrm{C}$ to determine the temperature at which the enzyme showed optimal activity. Water bath was used for activity measurements at different temperatures. The optimum temperature of the enzymes was determined by the results 


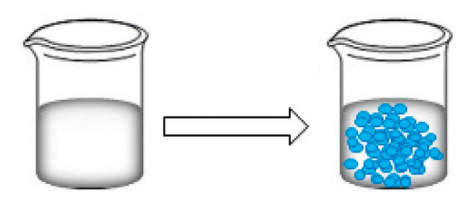

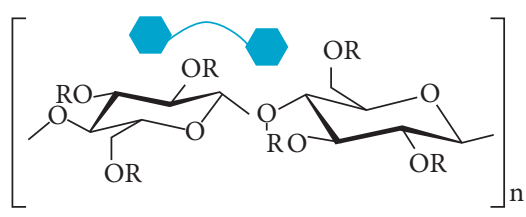

$\mathrm{CMC}$
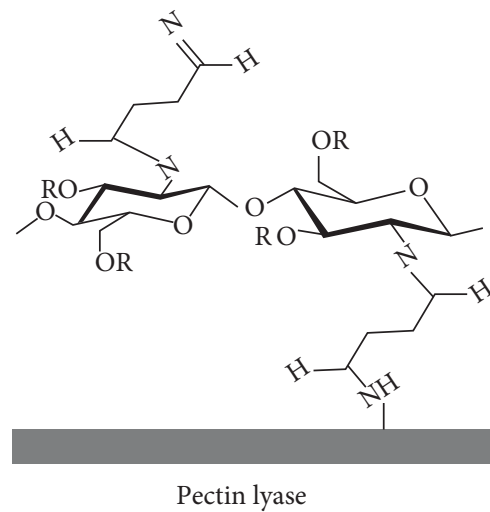

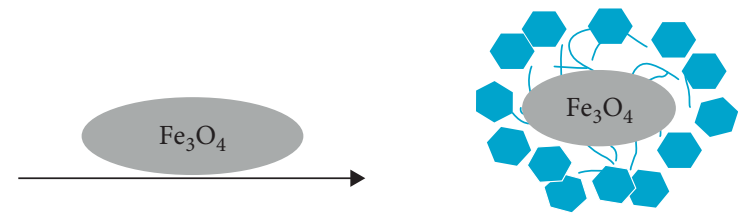

$\overbrace{\mathrm{O}}$

Glutaraldehyde

FIgURE 1: Immobilization reaction of PNL enzyme to cellulosic structures of glutaraldehyde modified magnetic nano-CMC.

obtained. To determine the stable temperature of the enzyme; efficacy measurements were made at a temperature range of $10-90^{\circ} \mathrm{C}$. For each temperature test was created reaction environments and measurements were performed every 15 minutes for 2 hours. The blank sample was prepared by replacing the enzyme with distilled water and all kinetic measurements were read spectrophotometrically against the blank sample [32].

\subsection{Characterization of Free and Immobilized Enzymes.} $V_{\max }$ and $K_{\mathrm{M}}$ were determined for the pectin substrate of both free and immobilized pectin lyase enzymes. By using different substrates (pectin, locust bean gum, and chitin), PNL activity measurements in the concentrations range of 0.25 to $1.5 \mathrm{mM}$ were made and Lineweaver-Burk plots were plotted. Then, maximum reaction rate $\left(V_{\max }\right)$ and Michaelis-Menten constant $\left(K_{\mathrm{M}}\right)$ values were determined.

\subsection{Application of Immobilized Enzyme in Fruit Juice Clarity.} The effects of free and immobilized pectin lyase enzymes on the clarity and disintegration of grape (black), apple (red), and plum (black) juices were investigated. The fruits were homogenized with a blender. The purees were then diluted $1 / 1$ with distilled water in the beakers and $2 \mathrm{~mL}$ of enzyme and homogenate were added to each group separately. Control, free and immobilized enzyme addition groups were formed. The sample prepared by adding $2 \mathrm{~mL}$ of pure water to 10 grams of fruit puree was used as control. The beakers were incubated for 5 hours with stirring in a $50^{\circ} \mathrm{C}$ water bath.
After cooling the purees, the juices were obtained by vacuum filtration through filter paper. After the juice was removed, the remaining fruit extract was dried at $105^{\circ} \mathrm{C}$ until constant weighing.

2.15. Structural Characterization of Support Material. Structural and morphological properties of free and immobilized pectin lyase magnetized by modifying with $\mathrm{Fe}_{3} \mathrm{O}_{4}$ NPs were investigated using scanning electron microscopy (SEM) (JEOL (JSM) 6400), X-ray diffraction (XRD) analysis (Rigaku-Miniflex X-ray diffraction system), and Fourier transform infrared spectroscopy (FTIR) (Mattson 1000 FTIR spectrophotometer) techniques.

2.16. Statistical Analysis. Data are presented as the mean \pm standard deviation of each treatment. Data were analyzed for statistical significance using analysis of variance (ANOVA) followed by the Tukey test $(p=0.05)$ (IBM SPSS Statistics 20, USA).

\section{Results and Discussion}

The pectin lyase enzyme was produced extracellularly from Acinetobacter calcoaceticus bacteria and immobilized with high efficiency by using CMC which has antioxidant, anticancer, antifungal, and antivirus properties [22]. 
3.1. Characterization of Purified Pectin Lyase from Acinetobacter calcoaceticus. Purification of the extracellularly produced pectin lyase enzyme from Acinetobacter calcoaceticus was carried out by a three-phase separation technique [6]. For this purpose, first, the $n$-butanol concentration was optimized and the maximum pectin lyase enzyme activity was determined according to the activity measurements at which 1:0.5 (extract: $n$-butanol) was obtained. Subsequently, at the optimum $n$-butanol concentration determined for purification of the PNL enzyme, the first ammonium sulfate precipitation was carried out between $20 \%$ and $80 \%$. The highest PNL enzyme activity was obtained at $60 \%$. The second ammonium sulfate precipitation was carried out at a concentration of $65-75 \%$ and the highest PNL activity was determined to be at $70 \%$ ammonium sulfate concentration. The pectin lyase enzyme was purified by three-phase separation technique from Acinetobacter calcoaceticus bacteria with a yield of $25.5 \%$ and 192.58 -fold (Table 1).

In some previous researches, PNL enzyme was reported to be purified 30.9, 36.36, and 58.01 times from bacteria such as Brevibacillus borstelensis [5], Bacillus pumilus [32], Aspergillus flavus [33], respectively. In this study, the PNL enzyme was purified using the triple separation technique. The TPP method, previously used in the purification of mannanase [6] and phytase [7] enzymes, has also been used to purify the pectin lyase enzyme. The purification coefficient for PNL purified by TPP method from Pseudomonas putida for the first time was determined as 192.58 [24]. The high effect achieved by this method has shown that this method we use in the purification process of the PNL enzyme is a useful approach.

\subsection{Preparation of Nanomagnetic $C M C$ and Immobilization} of Purified Pectin Lyase. Intermediate reagents are often used to create strong cross-links in enzyme immobilization. The most commonly used bifunctional cross-linking reagent is glutaraldehyde because it is cheap and can easily bound to enzymes [32]. L-glutaraldehyde was used as intermediate reagent in here too. The pectin lyase enzyme purified from Acinetobacter calcoaceticus was covalently immobilized to the surface of the CMC support material activated by a $1 \%$ L-glutaraldehyde solution in a suitable incubation medium $\left(30^{\circ} \mathrm{C}\right.$ for 60 minutes). The amount of protein, pectin lyase enzyme bound to magnetic CMC NPs was determined against time by making measurements in samples taken at different time intervals in reaction medium using Warburg and Bradford methods [31]. The carboxymethyl cellulose was activated with glutaraldehyde, thereby increasing the roughness of the surface after immobilization of the enzyme via the glutaraldehyde intermediate arm, allowing the enzyme to bind to the surface [20] (Figure 1).

3.3. Effect of Incubation Time, $p H$, and Temperature on Immobilization of PNL Enzyme on Magnetic CMC. Optimal pH and temperature values were determined by covalent immobilization of purified pectin lyase enzyme to the magnetized CMC NPs surface which was magnetized with nano-
$\mathrm{Fe}_{3} \mathrm{O}_{4}$. The purified PNL enzyme was immobilized using appropriate buffers at $\mathrm{pH} 3-8$ and the relative activity (\%) of the immobilized PNL enzyme was calculated. Accordingly, it was determined that the purified pectin lyase enzyme binds to a high level of support material at $\mathrm{pH} 8.0$ and $30^{\circ} \mathrm{C}$. The immobilization was then monitored for 7 hours to determine the optimal immobilization time at $\mathrm{pH} 8.0$ and $30^{\circ} \mathrm{C}$ (Figures 2(a) and 2(b)). The purified PNL enzyme was found to bind to the magnetized CMC NPs support material after 90 minutes at $80 \%$ rate (Figure 2(c)). Maximum binding rates of the pectin lyase to support materials were determined as $85 \%$ [16] and 87.2 [7] in previous studies.

\subsection{Biochemical Properties of Free and Immobilized Pectin Lyase}

3.4.1. Effect of Temperature and $p H$. The reaction was carried out at 10 to $90^{\circ} \mathrm{C}$ using pectin as a substrate at $\mathrm{pH} 8.0$ for a 90-minute incubation period for the free and immobilized pectin lyase enzyme. The maximum enzyme activity for free and immobilized pectin lyase was found at $50^{\circ} \mathrm{C}$ and was found to be consistent with the results of PNL enzymes reported by Lei and $\mathrm{Bi}$ [34] and Babagil [35]. At the temperatures above $50^{\circ} \mathrm{C}$, both free and immobilized pectinase activities decreased (Figure 3(a)). This value was obtained by taking into consideration $\mathrm{pH}$, temperature, and time to which the enzyme is stable (Figure 2). The enzyme substrate reaction was carried out at $30^{\circ} \mathrm{C}$ for 90 minutes with $\mathrm{pH}$ changing from 2.0 to 9.0. The optimum $\mathrm{pH}$ for the free and immobilized pectin lyase enzyme was found to be 8.0 (Figure 3(b)). It was determined that the optimum $\mathrm{pH}$ and optimum temperature values of pure pectin lyase obtained from different sources are generally between $\mathrm{pH} 4.5-10$ and $30-70^{\circ} \mathrm{C}[4,34-36]$.

\section{5. $p H$ Stability and Thermal Stability}

3.5.1. $p H$ Stability. The free and immobilized pectin lyase enzymes were incubated at $4^{\circ} \mathrm{C}$ for 1 hour using $\mathrm{pH} 3$ to 5 acetate buffer, $\mathrm{pH} 6$ to 7 phosphate buffer and $\mathrm{pH} 8$ to 9 Tris/ $\mathrm{HCl}$ buffer and their activities was measured. The results obtained are shown in Figure 4(a). It is understood from the results obtained that the immobilized PNL enzyme becomes more resistant to temperature compared to the free enzyme. From the results obtained, it was determined that the free enzyme retains $40 \%$ of the activity and the immobilized enzyme retains $78 \%$ of its activity at $\mathrm{pH} 3$. It was also retained $86 \%$ of the activity of free PNL and $57 \%$ of the activity of immobilized pectin lyase at $\mathrm{pH} 9.0$. As can be seen from the results, the immobilized pectin lyase enzyme activity is more stable at different $\mathrm{pH}$.

3.5.2. Thermal Stability. Enzymes, like other proteins, are generally heat sensitive and can be inhibited. However, immobilized enzymes are more resistant to high temperatures. The thermal inactivation rates of the soluble and immobilized enzyme were examined in the range of 10 to $100^{\circ} \mathrm{C}$ at $\mathrm{pH} 8.0$ in $50 \mathrm{mM} \mathrm{Na-phosphate} \mathrm{buffer.} \mathrm{The}$ 
TABLE 1: The purification process of purified pectin lyase enzyme from Acinetobacter calcoaceticus.

\begin{tabular}{lcccccccc}
\hline Fraction & $\begin{array}{c}\text { Volume } \\
(\mathrm{mL})\end{array}$ & $\begin{array}{c}\text { Activity } \\
(\mathrm{IU})\end{array}$ & $\begin{array}{c}\text { Total activity } \\
(\mathrm{IU})\end{array}$ & $\begin{array}{c}\text { Protein } \\
(\mathrm{mg} / \mathrm{mL})\end{array}$ & $\begin{array}{c}\text { Total protein } \\
(\mathrm{mg})\end{array}$ & $\begin{array}{c}\text { Specific activity } \\
(\mathrm{IU} / \mathrm{mg})\end{array}$ & $\begin{array}{c}\text { Purification } \\
\text { fold }\end{array}$ & $\begin{array}{c}\text { Yield } \\
(\%)\end{array}$ \\
\hline Crude extract & 60 & 248.1 & 14886 & 1441.4 & 86484 & 36.17 & - \\
$n$-butanol $(1: 0.5)$ & 20 & 214.4 & 4288 & 183.4 & 3668 & 1.16 & 6.87 \\
$1^{\text {st }}\left(\mathrm{NH}_{4}\right)_{2} \mathrm{SO}_{4}(60 \%)$ & 20 & 199.75 & 3995 & 27.48 & 549.6 & 28.8 \\
$2^{\text {nd }}\left(\mathrm{NH}_{4}\right)_{2} \mathrm{SO}_{4}(70 \%)$ & 20 & 189.9 & 3798 & 5.8 & 116 & 32.75 & 42.75 & 26.8 \\
\hline
\end{tabular}

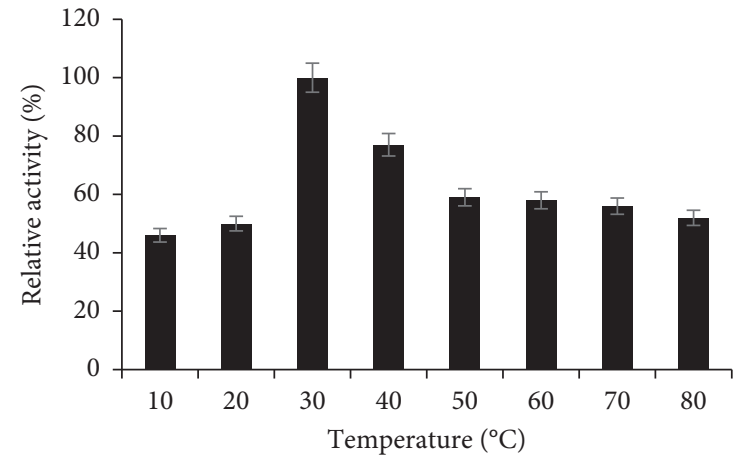

(a)

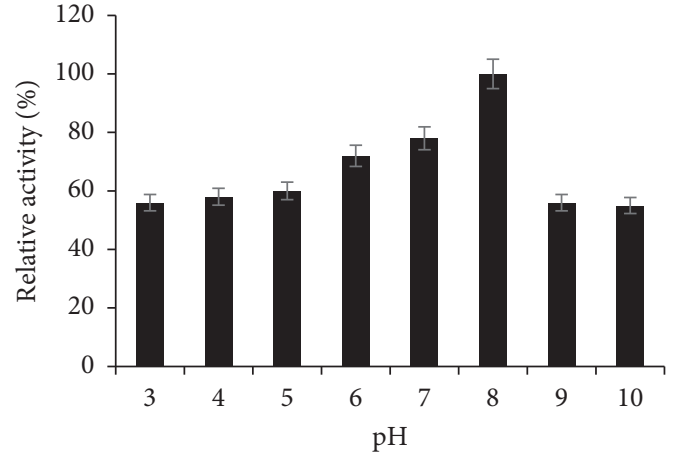

(b)

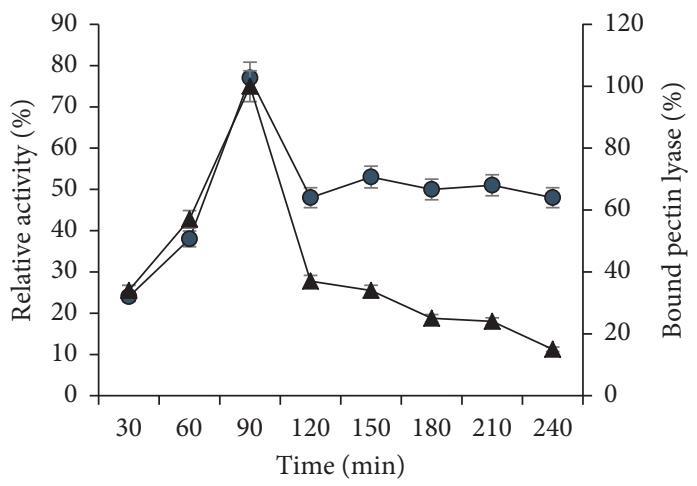

(c)

FIGURE 2: Results of the effect of temperature (a), pH (b) and incubation time (c), and on immobilization of PNL enzyme on magnetic nanoCMC.

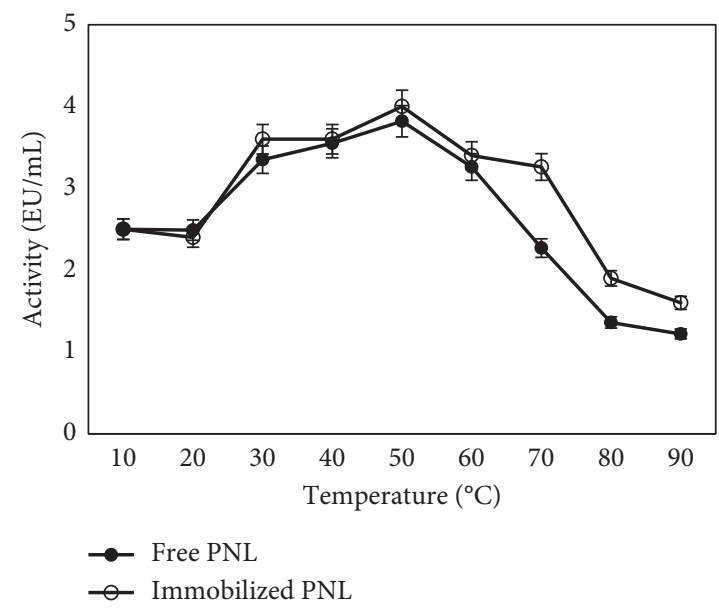

(a)

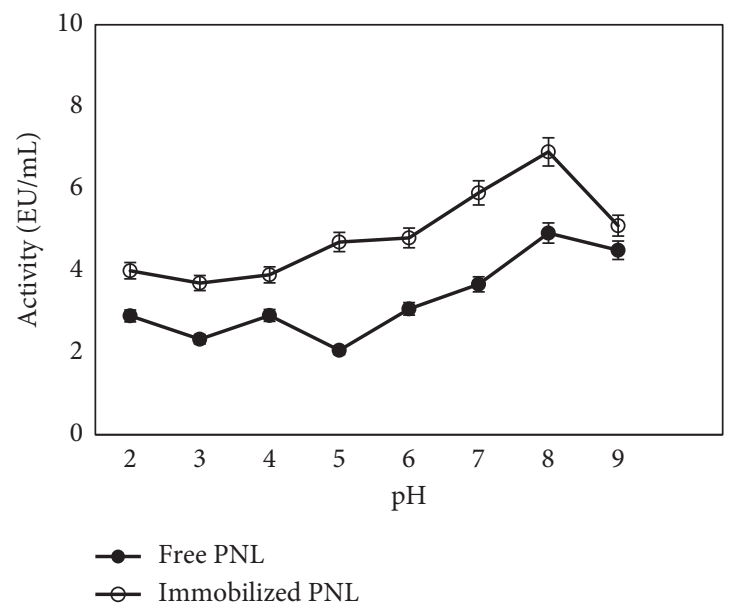

(b)

Figure 3: The effects of temperature (a) and $\mathrm{pH}(\mathrm{b})$ on activities of free and immobilized PNL enzymes. 


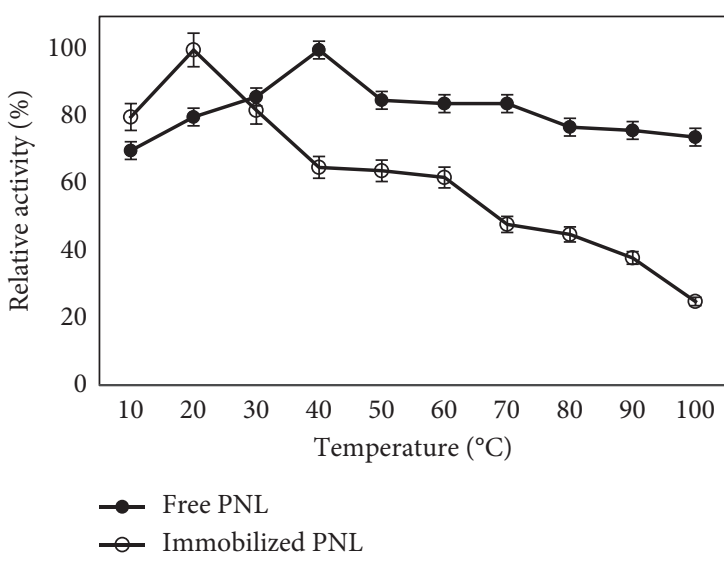

(a)

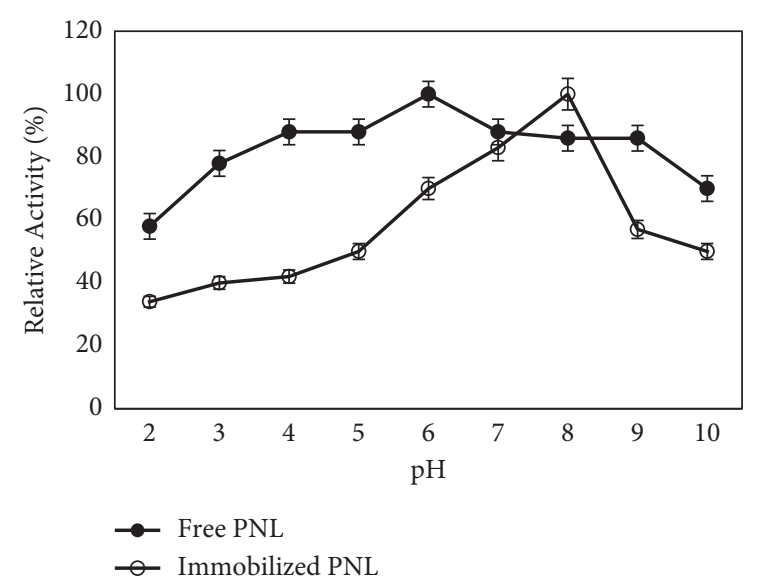

(b)

FIgURE 4: (a) pH stability and (b) thermal stability for free and immobilized PNL.

thermostability of the immobilized pectin lyase was measured by comparison with the free pectin lyase as shown in Figure 4(b). The free PNL enzyme lost approximately $75 \%$ of its activity at $90^{\circ} \mathrm{C}$ after 1 hour of heat treatment, while it lost only $26 \%$ of immobilized pectin lyase activity. Studies have shown that immobilized PNL enzyme generally increases thermal and $\mathrm{pH}$ stability compared to soluble enzymes $[24,36]$.

3.6. Characterization of Free and Immobilized PNL Enzymes. The affinities of immobilized pectin lyase (IMB-PNL) and free pectin lyase (F-PNL) enzymes were compared for pectin, gum, and chitin substrates and it was determined that IMB-PNL showed higher activity against all substrates (Table 2).

$V_{\max }, K_{\mathrm{M}}$, and catalytic efficiency were determined by measuring initial reaction rates and varying the amount of substrate. In addition, the enzyme kinetic parameters were determined using different substrates and it was observed that pectin is the best substrate. Similarly, also in previous studies, pectin was determined as the most suitable substrate $[24,35]$. The results obtained in the study shown that $V_{\max }$ values of IMB-PNL enzyme against all substrates increased and $K_{\mathrm{M}}$ values decreased. In the reactions where pectin is used as substrate and $K_{\mathrm{M}}$ values are $1.02 \mathrm{mg} / \mathrm{mL}$ for free enzyme, while this value for IMB-PNL is $0.88 \mathrm{mg} / \mathrm{mL}$. $V_{\max }$ values were determined as $18.01 \mathrm{mmol} / \mathrm{Lmin}$ for free enzyme and $24.02 \mathrm{mmol} / \mathrm{Lmin}$ for IMB-PNL. It is also seen that the affinity of the enzyme for the pectin substrate is high as in a previous study and increased significantly [17]. It can be thought that the decrease in the value of $K_{\mathrm{M}}$ and increase in $V_{\max }$ of the immobilized PNL enzyme compared to the free enzyme is due to the more stable structure of the immobilized PNL enzyme.

3.7. SDS-PAGE Electrophoresis. SDS-polyacrylamide gel electrophoresis was performed to check the purity and subunit number of the pectin lyase enzyme purified by triple phase separation (TPP) from Acinetobacter calcoaceticus. The resulting band images were photographed and are given in Figure 5. The gel images of PNL enzyme obtained from Acinetobacter calcoaceticus bacteria were compared with standard protein. Single protein band was obtained and molecular weight was determined as $33 \mathrm{kDa}$. PNL enzymes produced from Bacillus pumilus (P9) [32], Aspergillus flavus [33], and Penicillium chrysogenum [37] bacteria have $25 \mathrm{kDa}$, $38 \mathrm{kDa}$, and $31 \mathrm{kDa}$ molecular weights, respectively.

3.8. Structural Characterization of Support Material. The structure of immobilized PNL on magnetite-CMC NPs in SEM images is shown in Figure 6. The distribution of $\mathrm{Fe}_{3} \mathrm{O}_{4}$ NPs on the surface is clearly seen from SEM images. After the immobilization of the enzyme via the glutaraldehyde intermediate arm, the roughness of the surface increases and the surface binds with the enzyme. In addition, the surface of the magnetic CMC NPs from Figure 6 was observed to be very rough than the natural $\mathrm{CMC}$, and it was concluded that the structure of the support material was suitable for modification with nanomaterials and immobilization with PNL enzyme. It also has large-scale support and structural stability. It has also been shown in our previous studies that the cellulosic structure of the lily flower is a good support for enzyme immobilization [24].

3.9. X-Ray Diffraction (XRD) Analysis. XRD patterns of free enzyme magnetite-CMC NPs and purified pectin lyase immobilized magnetite-CMC NPs are shown in Figure 7.

The XRD pattern of CMC exhibits broad diffraction peaks at $2 \theta=30.25^{\circ}, 35.64^{\circ}, 43.52^{\circ}, 53.72^{\circ}, 57.41^{\circ}$, and $63.03^{\circ}$ which are typical fingerprints of $\mathrm{Fe}_{3} \mathrm{O}_{4}$ structure [38].

Energy Distribution X-ray analysis spectroscopy (EDX) revealed the presence of elements of free and immobilized pectin lyase with magnetite-CMC NPs structures (Figure 4 and Tables 2 and 3 ).

3.10. FT-IR Analysis. The structure of support material which immobilized and purified PNL enzyme onto modified CMC with $\mathrm{Fe}_{3} \mathrm{O}_{4}$ NPs was analyzed by FTIR. . Figure 8 
TABLE 2: $V_{\max }$ and $K_{\mathrm{M}}$ values of pure PNL and NMF-PNL enzymes (magnetic nano-CMC-PNL) for the substrates of pectin, locust bean gum, and chitin.

\begin{tabular}{lcccccc}
\hline & \multicolumn{2}{c}{ Pectin } & \multicolumn{2}{c}{ Locust bean gum } & \multicolumn{2}{c}{ Chitin } \\
& $V_{\max }(\mu \mathrm{mol} / \mathrm{Lmin})$ & $K_{\mathrm{M}}(\mathrm{mg} / \mathrm{mL})$ & $V_{\max }(\mu \mathrm{mol} / \mathrm{Lmin})$ & $K_{\mathrm{M}}(\mathrm{mg} / \mathrm{mL})$ & $V_{\max }(\mu \mathrm{mol} / \mathrm{Lmin})$ & $K_{\mathrm{M}}(\mathrm{mg} / \mathrm{mL})$ \\
\hline Pure PNL & 18.01 & 1.02 & 1.47 & 0.71 & 1.89 & 1.08 \\
NMF-PNL & 24.02 & 0.88 & 2.08 & 0.68 & 2.54 & 1.02 \\
\hline
\end{tabular}

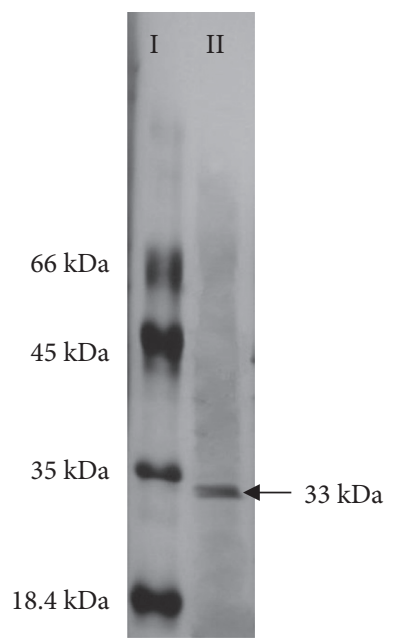

FIGURE 5: SDS-PAGE electrophoresis gel image of standard proteins (I) and purified pectin lyase enzyme from Acinetobacter calcoaceticus (II). Bovine serum albumin (BSA) $(66 \mathrm{kDa})$, ovalbumin $(45 \mathrm{kDa})$, lactate dehydrogenase $(35 \mathrm{kDa}), \mathrm{REase}$ Bsp $98 \mathrm{i}(25.0 \mathrm{kDa})$, and $\beta$-lactoglobulin $(18.4 \mathrm{kDa})$.

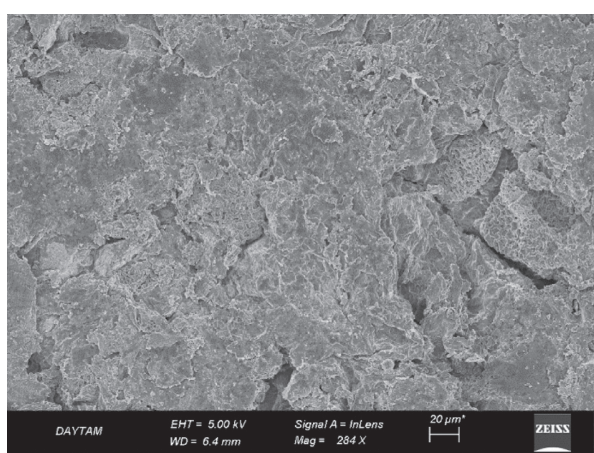

(a)

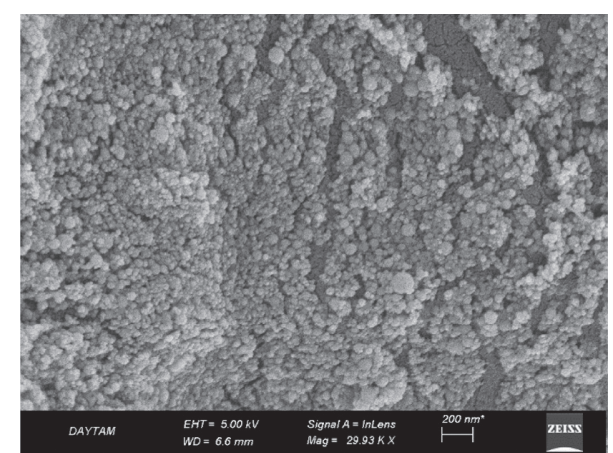

(b)

FIGURE 6: SEM images of before (a) and after (b) immobilized PNL on magnetic nano-CMC.

shows the FT-IR spectrum of the structure of the IM-PNL enzyme on the magnetic CMC support material. It is seen from the spectrum that the characteristic absorption of $\mathrm{Fe}-\mathrm{O}$ bond of $\mathrm{Fe}_{3} \mathrm{O}_{4}$ structure is $534 \mathrm{~cm}^{-1}$ and $638 \mathrm{~cm}^{-1}$, and the characteristic absorption of $-\mathrm{OH}$ bond is $3390 \mathrm{~cm}^{-1}$. The vibrations at $1404 \mathrm{~cm}^{-1}$ and $1608 \mathrm{~cm}^{-1}$ are characteristic peaks of the COO-Fe bond which may be due to the reaction of hydroxide radical groups on the $\mathrm{Fe}_{3} \mathrm{O}_{4}$ surface with the carboxylate anion contained in the cellulosic structure of the CMC. The peaks at $2850 \mathrm{~cm}^{-1}$ and $2917 \mathrm{~cm}^{-1}$ are due to vibration of the alkyl groups (at $-\mathrm{CH}_{2}$ and $-\mathrm{CH}_{3}$ ) of the cellulosic structure (CMC).
In Figure 8, the tensile vibration peaks belonged to $-\mathrm{OH}$ and $-\mathrm{NH}$ at 3419.79 and $3437.15 \mathrm{~cm}^{-1}$, respectively. In addition, the peak between 1514.12 and $1560.41 \mathrm{~cm}^{-1}$ showed the bending of $-\mathrm{NH}_{2}$. The shift observed in the band position is due to the cross-links between magnetic CMC and L-glutaraldehyde for copolymer modification.

3.11. Fruit Juice Clarification with Pectin Lyase. Treatment of fruit juices with low cost and quality application is an important target in food industry application. The biggest problem encountered in the preparation of many juices and wines other than citrus is the unwanted turbidity. 


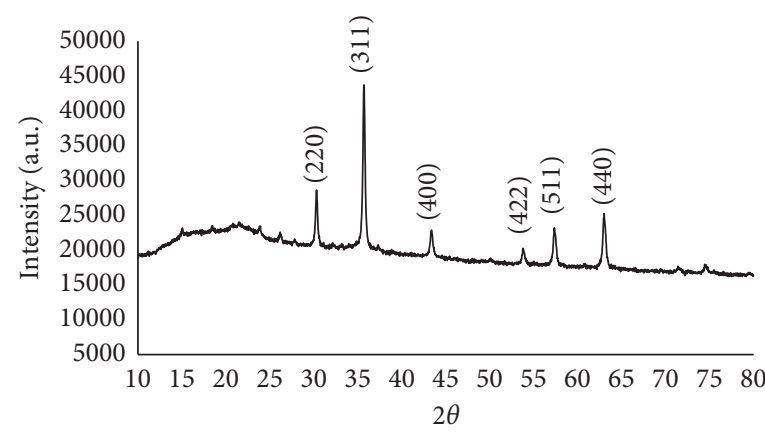

FIGURE 7: XRD patterns of IM-PNL on magnetic nano-CMC.

TABle 3: Degradation rates of dry matter in fruits control, treated with free and immobilized pectin lyase (PNL) enzyme.

\begin{tabular}{|c|c|c|c|c|c|c|c|c|c|c|}
\hline \multirow{3}{*}{ Fruit $(10 \mathrm{~g})$} & \multicolumn{6}{|c|}{ Dry weight } & \multicolumn{3}{|c|}{ Increasing volume $(\mathrm{mL})$} & \multirow{3}{*}{$\% \mathrm{C}$} \\
\hline & \multicolumn{2}{|c|}{ Control } & \multicolumn{2}{|c|}{ Free PNL } & \multicolumn{2}{|c|}{$\begin{array}{c}\text { Immobilized } \\
\text { PNL }\end{array}$} & \multirow{2}{*}{ Control } & \multirow[t]{2}{*}{ Free PNL } & \multirow{2}{*}{ Immobilized PNL } & \\
\hline & DW (g) & $\% \mathrm{D}$ & DW (g) & $\% \mathrm{D}$ & DW (g) & $\% \mathrm{D}$ & & & & \\
\hline Peach & 0.188 & 1.9 & 0.177 & 1.8 & 0.169 & 1.7 & 5.0 & 5.5 & 6.5 & 21 \\
\hline Apple & 0.176 & 1.8 & 0.165 & 1.7 & 0.080 & 0.8 & 6.3 & 6.0 & 8.5 & 15 \\
\hline Black plum & 0.191 & 1.9 & 0.097 & 1 & 0.087 & 0.9 & 7.0 & 8.0 & 9.8 & 23 \\
\hline Black grape & 0.178 & 1.8 & 0.160 & 1.6 & 0.126 & 1.3 & 8.0 & 8.5 & 9.0 & 14 \\
\hline
\end{tabular}

DW: dry weight; $\mathrm{D} \%$ : decrease rate; \%C: clarification rate.

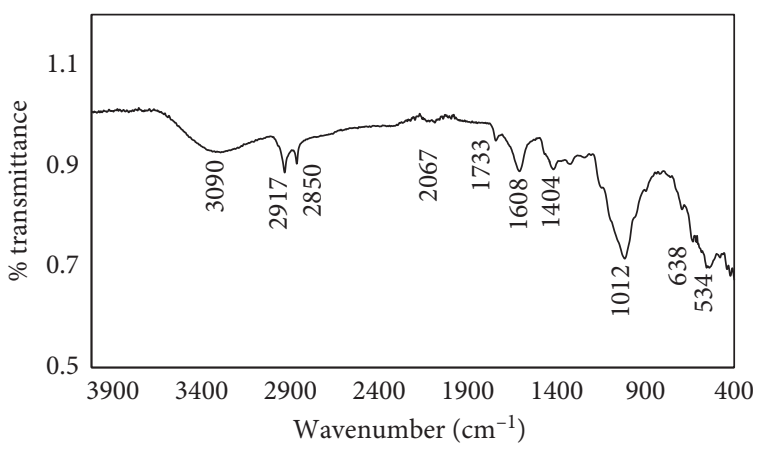

FIGURE 8: FT-IR spectrum of modified CMC with nanomagnetic and purified PNL immobilized onto magnetic nano-CMC.

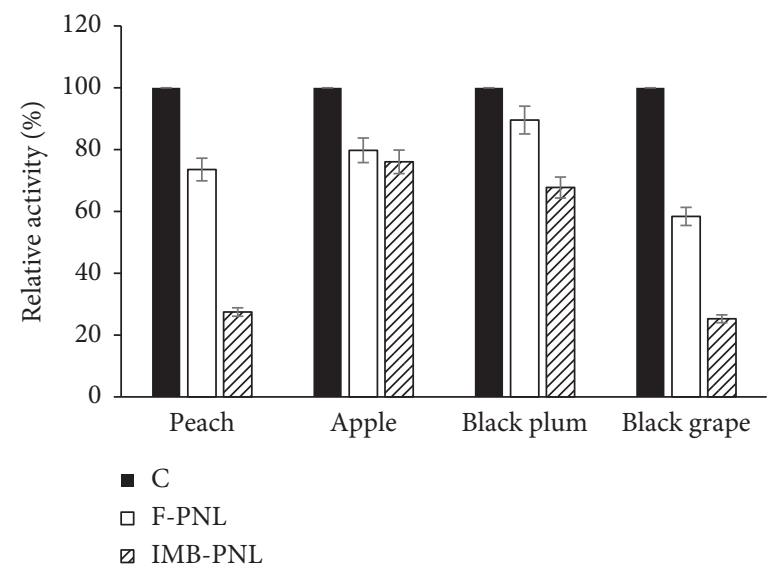

Figure 9: Absorbance \% changes in all fruit juice filtrates control (C) treated with free (F-PNL) and immobilized pectin lyase (IMB-PNL). 
The turbidity in freshly produced juice is caused by suspension of polysaccharides such as pectin, cellulose, hemicellulose, starch, and lignin in the cell wall. In industrial fruit juice processing, pectinolytic enzymes are used to remove such turbidity [24, 39]. Enzymes in this group that act on plant polysaccharides cause the aggregation of cloud particles and the clarification of fruit juices. Especially pectin lyase breaking down the pectins, it increases fruit juice yield and provides clarification $[5,8,24,40]$. In this study, it was investigated whether free and immobilized PNL enzymes produced and purified from Acinetobacter calcoaceticus affect the degradation rate and clarity of the juice production process used in fruit juice production.

Experiments using free enzyme and immobilized enzyme in fruit juice clarification processes were compared with control experiment using pure water. In fruit juice production process, grape (black), peach, apple (red), and plum (black) fruits obtained from local markets were washed and homogenized. For this purpose, clarification \% rate was calculated by comparing the amount of dry matter remaining after filtration of the reaction medium prepared using $10 \mathrm{~g}$ fruit and the results are given in Table 3. The effects of free and immobilized PNL enzymes on grape (black), plum, peach and apple juice amounts, and clarification ratios were determined and the increasing volume values in the filtrates are shown in Table 3. As in previous studies, immobilized pectin lyase reduced the degree of turbidity at higher rate than free pectin lyase and caused an increase in fruit juice volume too (Figure 4) [35, 41]. In addition, the absorbance changes in all filtrates were determined by measuring optical densities at $660 \mathrm{~nm}$ and the results are shown in Figure 9 as reduction \% [12, 32]. We observed a decrease in dry weights of all fruit, and especially the decreasing values of apple and black plum were more than the others. Similarly, Demir and her group determined a significant increase in their volume for all fruit juices in their study (Table 3) [5]. In the previous study [40], it was determined that the amount of pectin in the fruit juice decreased after the juice was clarified with the enzyme. It was determined that the increasing volume and decreasing dry weight were more than free PNL in immobilized PNL and immobilized PNL was more effective than free PNL enzyme in clarifying juices (Table 3 ). We say from results that the magnetized IMB-PNL reduced the degrees of turbidity in peach, apple, black plum, and black grape, respectively, at $21 \%, 15 \%, 23 \%$, and $14 \%$ rates. Similarly, during the purification of apple juice, viscosity reduction was reported as $\sim 35 \%, 38.8 \%, \sim 4.5 \%$, and $\sim 36 \%$, respectively, by Busto et al. [36], Xu et al. [42], Yuan et al. [43], and Singh and Gupta [44] $([25,41-45])$.

\section{Conclusions}

The use of pectic enzymes obtained from bacteria in the food industry has attracted great attention in recent studies. It is also known that immobilization of these enzymes offers several advantages over processes using soluble enzymes. Having a good haze removal activity, pectin lyase has a possible and effective use in the fruit juice industry. In this study, the pectin lyase enzyme was purified from Acinetobacter calcoaceticus bacteria by the three-phase separation technique and immobilized via glutaraldehyde on CMS, which is a natural biomaterial and magnetized with $\mathrm{Fe}_{3} \mathrm{O}_{4}$ nanoparticles. The efficiency and reusability of the PNL enzyme obtained from Acinetobacter calcoaceticus have been increased immobilizing on CMS, a natural support material, and it was tried to obtain a more economical use. Among the various support materials used for the immobilization of enzymes, low-cost, nontoxic, renewable, biodegradable, and biocompatible cellulose and its derivatives are becoming increasingly important. The results here show that the immobilized PNL enzyme on CMS exhibits good reusability for pectin hydrolysis and is more effective than the free enzyme. In addition, it was also seen that immobilized enzymes showed a good agreement effective in clarifying the fruits juice. Immobilization with these nontoxic materials is important in the food industry to contribute to a sustainable nutrition system. It is conceivable to use such easily accessible and nontoxic natural support materials for the immobilization of different enzymes in the food industry.

\section{Data Availability}

The data used to support the findings of this study are available from the corresponding author upon request.

\section{Conflicts of Interest}

The authors declare that they have no conflicts of interest.

\section{References}

[1] G. Garg, A. Singh, A. Kaur, R. Singh, J. Kaur, and R. Mahajan, "Microbial pectinases: an ecofriendly tool of nature for industries," Biotechnology, vol. 6, no. 1, 2016.

[2] R. S. Jayani, S. Saxena, and R. Gupta, "Microbial pectinolytic enzymes: a review," Process Biochemistry, vol. 40, no. 9, pp. 2931-2944, 2005.

[3] J. Cao, "The pectin lyases in Arabidopsis thaliana: evolution, selection and expression profiles," Public Library of Science (PLoS one), vol. 7, no. 10, Article ID e46944, 2012.

[4] D. B. Pedrolli, A. C. Monteiro, E. Gomes, and E. C. Carmona, "Pectin and pectinases: production, characterization and industrial application of microbial pectinolytic enzymes," The Open Biotechnology Journal, vol. 3, no. 1, pp. 9-18, 2009.

[5] N. Demir, H. Nadaroglu, Y. Demir et al., "Purification and characterization of an alkaline pectin lyase produced by a newly isolated Brevibacillus borstelensis (P35) and its applications in fruit juice and oil extraction," European Food Research and Technology, vol. 239, no. 1, pp. 127-135, 2014.

[6] H. Nadaroglu and N. Dikbas, "Purification and characterization of a $\beta$-mannanase from Lactobacillus plantarum (ATCC $\left.{ }^{\circledR} 14917 \mathrm{TM}\right)$," International Journal of Innovative Research and reviews, vol. 2, no. 1, pp. 1-6, 2018.

[7] H. Onem and H. Nadaroglu, "Immobilization of purified phytase enzyme from Tirmit (Lactarius volemus) on coated chitosan with iron nanoparticles and investigation of its usability in cereal industry," Iranian Journal of Science and Technology, Transactions A: Science, vol. 42, no. 3, pp. 10631075, 2018. 
[8] V. Sorrivas, D. B. Genovese, and J. E. Lozano, "Effect of pectinolytic and amylolytic enzymes on apple juice turbidity," Journal of Food Processing and Preservation, vol. 30, no. 2, pp. 118-133, 2006.

[9] L. D. Magro, S. S. de Moura, B. E. Backes et al., "Immobilization of pectinase on chitosan-magnetic particles: influence of particle preparation protocol on enzyme properties for fruit juice clarification," Biotechnology Reports, vol. 24, Article ID e00373, 2019.

[10] R. A. Sheldon, "Enzyme immobilization: the quest for optimum performance," Advanced Synthesis \& Catalysis, vol. 349, no. 8-9, pp. 1289-1307, 2007.

[11] C. Mateo, J. M. Palomo, G. Fernandez-Lorente, J. M. Guisan, and R. Fernandez-Lafuente, "Improvement of enzyme activity, stability and selectivity via immobilization techniques," Enzyme and Microbial Technology, vol. 40, no. 6, pp. 1451$1463,2007$.

[12] B. Krajewska, "Application of chitin- and chitosan-based materials for enzyme immobilizations: a review," Enzyme and Microbial Technology, vol. 35, no. 2-3, pp. 126-139, 2004.

[13] H. L. Ramirez, L. Gómez Brizuela, J. Úbeda Iranzo, M. Arevalo-Villena, and A. I. Briones Pérez, "Pectinase immobilization on a chitosan-coated chitin support," Journal of Food Process Engineering, vol. 39, no. 1, pp. 97-104, 2016.

[14] M. Irshad, A. Murtza, M. Zafar, K. H. Bhatti, A. Rehman, and Z. Anwar, "Chitosan-immobilized pectinolytics with novel catalytic features and fruit juice clarification potentialities," International Journal of Biological Macromolecules, vol. 104, pp. 242-250, 2017.

[15] H. U. Rehman, A. Aman, A. Aman, A. Silipo, S. A. U. Molinaro, and A. Ansari, "Degradation of complex carbohydrate: immobilization of pectinase from Bacillus licheniformis KIBGE-IB21 using calcium alginate as a support," Food Chemistry, vol. 139, no. 1-4, pp. 1081-1086, 2013.

[16] P. Kohli and R. Gupta, "Application of calcium alginate immobilized and crude pectin lyase from Bacillus cereus in degumming of plant fibres," Biocatalysis and Biotransformation, vol. 37, no. 5, pp. 341-348, 2019.

[17] H. Horchani, I. Aissa, S. Ouertani, Z. Zarai, Y. Gargouri, and A. Sayari, "Staphylococcal lipases: biotechnological applications," Journal of Molecular Catalysis B: Enzymatic, vol. 76, pp. 125-132, 2012.

[18] K. Vijayaraghavan, D. Yamini, V. Ambika, and N. Sravya Sowdamini, "Trends in inulinase production - a review," Critical Reviews in Biotechnology, vol. 29, no. 1, pp. 67-77, 2009.

[19] A. A. Homaei, R. Sariri, F. Vianello, and R. Stevanato, "Enzyme immobilization: an update," Journal of Chemical Biology, vol. 6, no. 4, pp. 185-205, 2013.

[20] K. Kurita, "Controlled functionalization of the polysaccharide chitin," Progress in Polymer Science, vol. 26, no. 9, pp. 1921-1971, 2001.

[21] M. G. Peter, "Applications and environmental aspects of chitin and chitosan," Journal of Macromolecular Science, Part A, vol. 32, no. 4, pp. 629-640, 1995.

[22] Y. Liu and J. Y. Chen, "Enzyme immobilization on cellulose matrixes," Journal of Bioactive and Compatible Polymers, vol. 31, no. 6, pp. 553-567, 2016.

[23] J. Zdarta, A. S. Meyer, T. I. D. Jesionowski, and M. A. Pinelo, "General overview of support materials for enzyme immobilization: characteristics, properties, practical utility," Catalysts, vol. 8, no. 2, pp. 2-27, 2018.

[24] E. Tasgin, H. Nadaroglu, A. Babagil, and N. Demir, "Immobilization of purified pectin lyase from Pseudomonas putida onto magnetic lily flowers (Lilium candidum L.) nanoparticles and applicability in industrial processes," Molecules, vol. 25, no. 11, p. 2671, 2020.

[25] T. Mehmood, T. Saman, M. Irfan et al., "Pectinase production from Schizophyllum commune through central composite design using citrus waste and its immobilization for industrial exploitation," Waste and Biomass Valorization, vol. 10, no. 9, pp. 2527-2536, 2018.

[26] I.-M. Garbers, T. J. Britz, and R. C. Witthuhn, "PCR-based denaturing gradient gel electrophoretictypification and identification of the microbial consortium present in Kefir grains," World Journal of Microbiology \& Biotechnology, vol. 20, no. 7, pp. 687-693, 2004.

[27] P. C. Y. Woo, A. M. Y. Fung, S. K. P. Lau, and K.-Y. Yuen, "Identification by $16 \mathrm{~S}$ rRNA gene sequencing of Lactobacillus salivarius bacteremic cholecystitis," Journal of Clinical Microbiology, vol. 40, no. 1, pp. 265-267, 2002.

[28] P. Forsman, A. Tilsaia-Timisjarvi, and T. Alatossava, "Identification of staphylococcal and streptococcal causes of bovine mastitis using 16S-23S rRNA spacer regions," Microbiology, vol. 143, no. 11, pp. 3491-3500, 1997.

[29] M. Nedjma, N. Hoffmann, and A. Belarbi, "Selective and sensitive detection of pectin lyase activity using a colorimetric test: application to the screening of microorganisms possessing pectin lyase activity," Analytical and Biochemistry, vol. 291, no. 2, pp. 290-296, 2001.

[30] F. S. Alatawi, M. Monier, and N. H. Elsayed, "Amino functionalization of carboxymethyl cellulose for efficient immobilization of urease," International Journal of Biological Macromolecules, vol. 114, pp. 1018-1025, 2018.

[31] M. M. Bradford, "A rapid and sensitive method for the quantitation of microgram quantities of protein utilizing the principle of protein-dye binding," Analytical Biochemistry, vol. 72, no. 1-2, pp. 248-254, 1976.

[32] H. Nadaroglu, E. Taskin, A. Adiguzel, M. Gulluce, and N. Demir, "Production of a novel pectin lyase from Bacillus pumilus (P9), purification and characterization and fruit juice application," Romanian Biotechnology Letter, vol. 15, no. 2, pp. 5167-5176, 2010.

[33] S. Yadav, P. K. Yadav, D. Yadav, and K. D. S. Yadav, "Purification and characterization of an alkaline pectin lyase from Aspergillus flavus," Process Biochemistry, vol. 43, no. 5, pp. 547-552, 2008.

[34] Z. Lei and S. Bi, "The silica-coated chitosan particle from a layer-by-layer approach for pectinase immobilization," Enzyme and Microbial Technology, vol. 40, no. 5, pp. 1442-1447, 2007.

[35] A. Babagil, Purification and characterization of pectin lyase enzymes from microorganism, preparation of enzymic $\mathrm{Ca}^{2+}$ hybrid nanoflower structure and the investigation of use in fruit juice clarification, Ph.D. thesis, Ataturk University, Erzurum, Turkey, 2018.

[36] M. D. Busto, K. E. García-Tramontín, N. Ortega, and M. Perez-Mateos, "Preparation and properties of an immobilized pectin lyase for the treatment of fruit juices," Bioresource Technology, vol. 97, pp. 1477-1483, 2006.

[37] A. R. Banu, M. K. Devi, G. R. Gnanaprabhal, B. V. Pradeep, and M. Palaniswamiy, "Production and characterization of pectinase enzyme from Penicillium chrysogenum," Indian Journal of Science and Technology, vol. 3, no. 4, pp. 377-381, 2010.

[38] K. Ogawa, S. Hirano, T. Miyanishi, T. Yui, and T. Watanabe, "A new polymorph of chitosan," Macromolecules, vol. 17, no. 4, pp. 973-975, 1984. 
[39] M. Cerreti, K. Markošová, M. Esti, M. Rosenberg, and M. Rebroš, "Immobilisation of pectinases into PVA gel for fruit juice application," International Journal of Food Science \& Technology, vol. 52, no. 2, pp. 531-539, 2017.

[40] T. B. Dey and R. Banerjee, "Application of decolourized and partially purified polygalacturonase and $\alpha$-amylase in apple juice clarification," Brazilian Journal of Microbiology, vol. 45, no. 1, pp. 97-104, 2014.

[41] M. M. C. N. Soares, R. Silva, and E. Gomes, "Screening of bacterial strains for pectinolytic activity: characterization of the polygalacturonase produced by Bacillus sp," Revista de Microbiologia, vol. 30, no. 4, pp. 299-303, 1999.

[42] S. X. Xu, X. Qin, B. Liu et al., "An acidic pectin lyase from Aspergillus niger with favourable efficiency in fruit juice clarification," Letters in Applied Microbiology, vol. 60, no. 2, pp. 181-187, 2014.

[43] P. Yuan, K. Meng, H. Huang et al., "A novel acidic and lowtemperature-active endo-polygalacturonase from Penicillium sp. CGMCC 1669 with potential for application in apple juice clarification," Food Chemistry, vol. 129, no. 4, pp. 1369-1375, 2011.

[44] S. Singh and R. Gupta, "Apple juice clarification using fungal pectinolytic enzyme and gelatin," Indian Journal of Biotechnology, vol. 3, pp. 573-576, 2004.

[45] H. Nadaroglu, A. Alaylı Güngör, and S. Ince, "Synthesis of nanoparticles by green synthesis method," International Journal of Innovative Research and Reviews, vol. 1, no. 1, pp. 6-9, 2017. 